\title{
Rękopiśmienne Kantyczki po polsku z XVII wieku - problemy proweniencji i autorstwa
}

Halina Popławska 
nAP7S Seria IX 2003

\section{Halina Popławska}

\section{Rękopiśmienne Kantyczki po polsku z XVII wieku - problemy proweniencji i autorstwa}

$\mathrm{W}$

zbiorach Biblioteki Kórnickiej pod sygnaturą 1374 (jako Kantyczki po polsku) znajduje się siedemnastowieczna księga rękopiśmienna zawierająca zbiór pieśni religijnych. Manuskrypt ten zakupił dla Jana Dzialyńskiego jego bibliotekarz, Zygmunt Celichowski'.

14 września 1875 roku w Poznaniu Celichowski wziął udział w licytacji książek „po niejakim Kokoszyńskim"”, blizej nieznanym - nawet z imienia - kolekcjonerem z Wielkopolski. Zakupił 46 ksiązek i rękopisów oraz 90 broszur i pism ulotnych. Dwa dni później w liście do Jana Dzialyńskiego bibliotekarz podał spis nabytych książek. Na pierwszym miejscu umieścił rękopiśmienny zbiór pieśni religijnych, który opisal:

Manuskrypt. Kantyczki z w. 17. lub początku 18., pisane w pewnym zakonie żeńskim, brakuje kilkı kart z początku $(\ldots)^{3}$.

Zygmunt Celichowski nie był pewny swoich ustaleń, dlatego informację o proweniencji: „z zakonu cystersek w Owińskach” umieścił na końcu opisu, ujmując ją w nawias i opatrując znakiem zapytania. Bibliotekarz sporządzał wykaz książek zakupionych w Poznaniu krótko po licytacji, nie mial zatem czasu na dokładne przyjrzenie się rękopisowi. Dziś można stwierdzić, iż na pewno nie pochodził on z zakonu cysterek. Powstał w innym żeńskim zakonie zgromadzeniu karmelitanck bosych. W tym miejscu warto podkreślić, iż na licytacji w Poznaniu bibliotekarz Jana Działyńskiego nabyl dwa starodruki karmelitańskie: wydany w Krako-

${ }^{1}$ OZygmuncic Celichowskim (1845-1923) szeroko pisze 1). Zagartowska, Bibliotckar , . Pamiçtnik Biblioteki Kórnickiej", z. 24. 1996, s. 9-38.

2 Z. Celichowski do J. Dzialyńskicgo, 16 IX 1875, rps Bibliotcki Kórnickicj (dalcj: BK), sygn. 7454, k. 337.

${ }^{3}$ Ibidem, k. 339. 
wie w 1696 roku traktat o sztuce umierania Praktyka dobrej smierci karmelity o. Cyryla od św. Franciszka oraz wydane w 1669 roku nauki duchowne i rozmyślania Nauki $i$ zabauki ${ }^{5}$, napisane co prawda nie przez karmelitę, ale stanowiące pierwotnie własność karmelitanek bosych konwentu poznańskiego. W jaki sposób omawiany wyżej manuskrypt trafil do zbiorów Kokoszyńskiego, trudno powiedzieć, być może wcześniej stanowił własność poznańskiego zgromadzenia karmelitanek bosych, chociaż nic nie wskazuje na to, aby w tym whaśnie konwencie powstal.

O karmelitańskiej proweniencji manuskryptu świadczy użycie w tekście kantyczki Żłób rzeczownika ..bosaczki", którym potocznie określano w XVII wieku karmelitanki bose:

Tu was zapraszam, wszystki Bosaczki,

Boście na świecie biedne żebraczki.

W Stowie wcielonym macie dość chleba,

Już wam od świata żebrać niè trzeba (s. 45).

Na środowisko karmelitanek bosych wskazują równiez Wierszyki na profesyję Matce Teresie Krakou'skiej (s. 62-63). Utwór poświęcony został najwybitniejszej siedemnastowiecznej karmelitance, Matce Teresie od Jezusa, Mariannie Marchockicj, profesce klasztoru św. Marcina w Krakowie, przeoryszy klasztoru lwowskiego, a następnie warszawskiego. Pieśń powstała z okazji ponowienia ślubów przez zakonnicę „pięćdziesiątego roku”, to znaczy w roku 165(), kiedy Marianna Marchocka była już przełożoną w klasztorze warszawskim.

Onawiana księga rękopiśmienna jest uszkodzona, brakuje jej kilku początkowych kart, w tym karty tytułowej. Zbiór pieśni rozpoczyna Kanty'zza siódma: Na Narodzenie Panskie Dzieciątka Pan Jezus. Po niej następuja pieśni opatrzone kolejną numeracją aż do kantyczki 99, z tym że numery 67 i 73 powtórzono błędnie. Dalej zamieszczono 43 teksty bez numeracji, posiadające jednak tytuł lub - w pojedynczych przypadkach - nazwę: Kantyczka.

Utwory te najprawdopodobnicj napisane zostały przcz kilka zakonnic. Można sądzić, iż Kant)'zka 91: Bethleem ułożona została przez nowicjuszkę. Świadczyć o tym mogą następujące stowa:

Żebrzę tego, Matki moje,

Dajcie na mię głosy swoje.

I dalej:

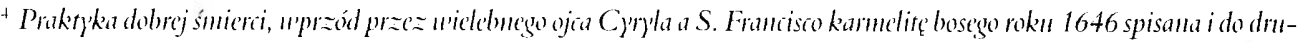

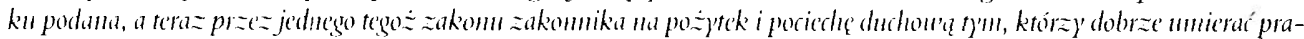

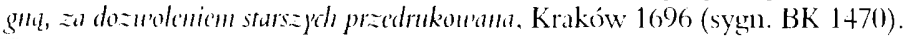

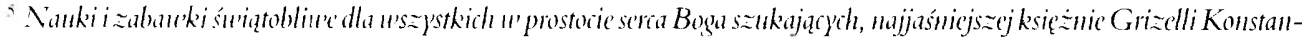

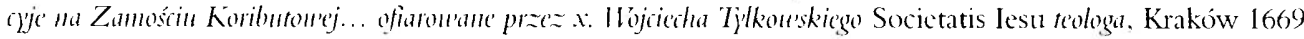
(sygn. BK 1+t3).
} 
Niźlim ja tę pieśń śpiewała,

Za klauzurę-1n się dostala (s. 39, 40)

Podobnic do pobytu w nowicjacie odwoluje się Kantyczka 92: Muzyka. Natomiast w kantyczce Aniołon'ie (pieśń bez numeracji) profeska zwraca się do młodych zakonnic:

Siostrzyczki nasze, co w nowicjacie,

Taką piosneczką Dziecię witajcie (s. 62)

Na końcowych kartach rękopisu (s. 67-85) kopistka umieściła cykl czterdziestu jeden pieśni religijnych autorstwa „Matki Eufrazyi”. Wiersze Matki Eufrazji opatrzone są numerami od 1 do 44, jednak po utworze Muzyka z informacją: Kantyczka 35 następuje Kantyczka 38 : Pieluszki, a z Kantyczki 44: ŚŚ [Śuiçci] Aniotonie zapisano zaledwie dwa początkowe wersy. Możliwe, że kopistka pomyliła się w oznaczeniu kolejności pieśni, ale możliwe jest również, że, przepisując z jakiegoś źródła, opuścila kantyczki 36 i 37, a zachowala, zgodnie z tym źródtem, porządek następnych utworów w zbiorze. Nie wiadono, czy wiersze zapisane w rękopiśmiennej księdze to wszystkie pieśni, jakie ulożyła Matka Eufrazja: z calą pewnością istniala jeszcze Kantyczka 44: jak można sądzić, była to kolęda poświęcona aniołom.

Cykl pieśni poprzedzony zostal informacją:

Poczynają się piosneczki składania W[ielebnej] Matki Eufrazyi, fundatorki czwartego konwentu naszego.

Sformulowanie „czwartego konwentu naszego” (w rękopisie numer zapisany cyfrą „4”) wydaje się precyzyjne i jednoznaczne. Wystarczy odwołać się do faktów z historii Karmelu na ziemiach Polski, Litwy i Rusi, aby w sposób nieomylny wskazać ów „Czwarty konwent”. Pierwsze zgromadzenic karmelitanek bosych pod wezwaniem św. Marcina powstalow 1612 roku w Krakowie. W ciągı półwiecza we wszystkich széściu głównych miastach i zarazem ośrodkach życia zakonnego Polski powstaly klasztory karmelitanek. W Lublinie uformowaly się dwa zgromadzenia: w 1624 roku klasztor św. Józefa i w 1649 klasztor Niepokalanego Poczęcia Najświętszej Maryi Panny. W roku 1638 z inicjatywy Stefana Paca powstał w Wilnie klasztor św. św. Józefa i Teresy. W 1642 roku ufundowany zostal klasztor we Lwowie (pod wezwaniem Matki Bożej Loretańskiej), a w 1649 konwent pod wezwaniem Ducha Świętego w Warszawie. Ostatnie spośród siedemnastowiecznych zgromadzeń karmelitanek bosych powstało w Poznaniu w 1665 roku". Chronologicznie zatem czwartym konwentem byl klasztor we Lwowie. Na jego fundację wyznaczono z klasztoru św. Marcina: Teresę od Jezusa, Mariannę Marchocką i Teresę Marię od św. Józefa, które w podróży do Lwowa miały zatrzymać się w klasztorze św. Józefa w Lublinie i wziąć ze sobą s. Angelę Aleksandrę od św. Teresy i s. Kata-

"Zob. o. Benignus J. Wanat, Zakon Karmelitón Bosyde " Polsce. Klasztory kurmeditón i karmelitanek bosy'd 1605-1975. Kraków 1979, s. 103-104: 619-668. 
rzynę od Wiecznej Mądrości” "Matka Eufrazyja” nie mogła być „fundatorką” konwentu lwowskiego; wykaz imion sióstr lwowskich pozwala stwierdzić, iż nie było wśród nich zakonnicy o imieniu Eufrazja ${ }^{\varnothing}$. Dwa imiona zakonne: Eufrazja oraz Katarzyna, które kilkakrotnie pojawia się w tekstach Kantyczek po polskn (dwukrotnie na s. 33 i raz na s. 76), potwierdzają wileńskie pochodzenie rękopisu. „Siostra Katarzyna” to najprawdopodobniej Katarzyna od Chrystusa Pana. Felicjanna Tyszkiewiczówna, córka Eustachego Tyszkiewicza, wojewody brzeskiego (profesja 27 lutego $16+2$ roku)".

Informacja - nazwijmy ją tak — tytułowa zawiera szereg ważnych wskazówek; jest niezwykle cenna, szczególnie w sytuacji, gdy większość karmelitańskich utworów to dzieła anonimowe. Badacz staje wobec interesującego zadania ustalenia, kim była „matka Eufrazyja”, autorka czterdziestu jeden pieśni. Zadanie to okazuje się nie tylko fascynującym problemem badawczym, ale również trudną zagadką historyczną, której rozwiązanie nie może chyba być jednoznaczne i niepodważahne. Źródla historyczne, jakimi dysponujemy w tej kwestii, są nieliczne i niezwykle skąpe. Poza kilkoma źródlami historycznymi z archiwum wileńskiego, dziś przechowywanymi w Archiwum Prowincji Karmelitów Bosych w Czernej, są to w zasadzie dwa obszerne dokumenty: Księga ży'ota, u' której się u'pisują imiona sióstrkarmelitanek bosych, któ-

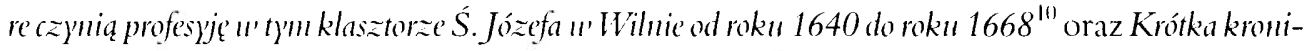
ka fundacyi karmelitanck bosyech klasztorn śluig̨te lgo Józefa "Wilnie, która stang̨ta "roku 1638, 18 Decembra ${ }^{11}$. Oba dokumenty wileńskiego klasztoru wydal ojciec Rafał Kalinowski ${ }^{12}$

Imię Eufrazja nie bylo zbyt częste wśród zakonnic wileńskiego klasztoru; może wskazywać przede wszystkim na dwie osoby: Eufrazję od św. Jacka i Eufrazję od św. Kazimierza. Obie mniszki petnity funkcję przeoryszy. Eufrazja od św. Jacka była pierwszą przeoryszą klasztoru w latach 1638-1648. Eufrazja od św. Kazimierza wybrana została na przeoryszę 21 marca 1656 roku, w czasie pobytu konwentu na Morawach. Urząd swój sprawowała przez trzy lata, do 1659 roku.

W 1685 roku do klasztoru w Wilnie wstąpila córka Augustyna Gradowskiego i Eleonory Zawiszanki. Przyjęła imię: Eufrazja Bogumila od Matki Bożej. Zapis w Księdze ży'ota... nie świadczy jednak o tym, by byla ona przeoryszą ${ }^{13}$.

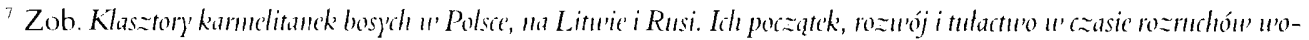

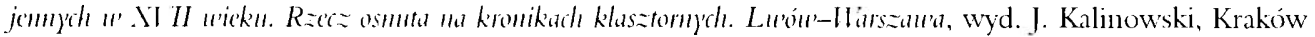
19()I, s. VIII.

${ }^{x}$ Ibidem. s. 15.

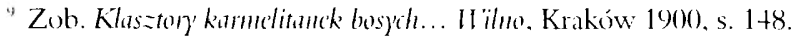

It Rps Archiwum Prowincji Karmclitów Busych w Czcrncj (dalej: AKBW) sygn. 24.

${ }^{12}$ Rps AKBW sygn. 22; obcjmujc lata 1638-165\%.

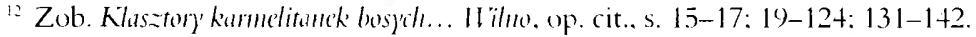

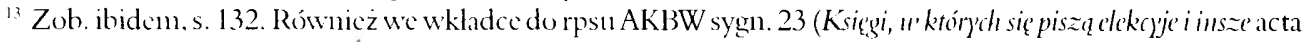

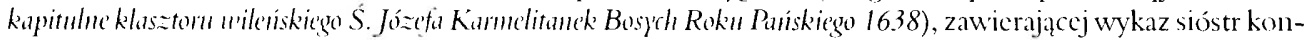
wentu wilcńskiego. przy imicniu ..Eufrazyja Bogumiła od Matki Bożej. Gradowska" postawiono literę̧ "S" (.,Siostra”). gdy w przypadku sióstr pehuiących funkcję przcoryszy zaw'sze podawano: „M” (.,Matka”). 
Kolejną ważną wskazówką jest to, iż Eufrazja, której pełnego imienia nie podano (brak określenia patrona), a o której wiemy, iż sprawowala finkcje przeoryszy, gdyż nazwana jest „Wielebną Matką”, określona została równicz jako „Fundatorka”. Tytuł „fundatora” w świetle pism karmelitańskich przysluguje trzem kategoriom osób. Oznacza przede wszystkim osobę, z której inicjatywy i nadania majątkowego powstał klasztor. Fundatorami zgromadzenia św. św. Józefa i Teresy w Wilnie byli Stefan Pac (podkanclerzy wielki litewski, wojewoda trocki) i jego żona Anna Maria Ancilla z Rudominów Dusiatyckich Pacowa. Introdukcja do klasztoru nastąpila 18 grudnia 1638 roku $^{1+}$.

Fundatorkami klasztoru nazywa się również zakonnice, które przybyly na nową fundację z klasztoru macierzystego. W tym sensie fundatorką klasztoru wileńskiego byla Eufiazja od św. Jacka (Teodora Piaseczyníska), sprowadzona w 1638 roku wraz z trzema innymi siostrami z klasztoru lubelskiego i krakowskiego. Rękopiśmienma Księga ży'u'ota... „Wielebną Matkę Eufrazyję od św. Jacka” nazywa „Pierwszą Fundatorka”" ${ }^{15}$. Eufrazja od św. Jacka była córką Wawrzyníca Piaseczyńskiego, podkomorzego bracławskiego, i Magdaleny Dębickiej. Profesję zakonną przyjęła w klasztorze św. Marcina w Krakowie 26 maja 1618 roku, w wieku dwudziestu pięciu lat. Wraz z trzema zakonnicami skierowana została na nową fundację do Lublina (klasztor św. Józefa), gdzie przybyła I listopada 1624 roku. Pełniła funkcję przeoryszy klasztoru lubelskiego, gdy w 1638 roku udała się do nowo powstałego zgromadzenia w Wilnie. Tu zmarła 7 kwietnia 1648 roku, pelniąc finkcję przeoryszy ${ }^{16}$.

Wkladka do Ksiqu, u' których się piszq cleke'jé... z Archiwum Karmelitanek Bosych w Wilnie, zawierająca listę wszystkich zakonnic wileńskich, po wiadoności:

Przybyły na fundacyję tego klasztoru cztery zakomnice, imiona ich są te (...) na pierwszym miejscu podaje dane:

Matka Eufrazyja od św. Jacka, fundatorka, na świecie Teodora Piaseczyńska, uczyniła profesyję w klasztorze krakowskim r. 1618 d. 26 maja. Umarła r. 1648 d. 7 Aprila, mając lat 57, w zakonie 32, na przełożeństwie zakończyła życie ${ }^{17}$.

W kronice klasztoru wileńskiego, sporządzonej ıajprawdopodobniej przez siostrę Katarzynę od Chrystusa Pana (Felicjannę Tyszkiewicz, 1625-1683), szczególowo opisano okoliczności śmierci Eufrazji od św. Jacka. Fundatorka i przeorysza klasztoru zmarła o siódmej ra-

\footnotetext{
it Zob. B. J. Wanat, op. cit., s. 6,37-6,38.

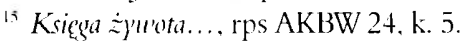

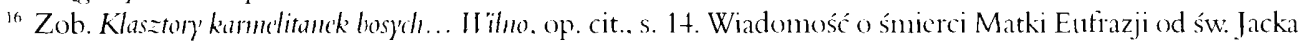

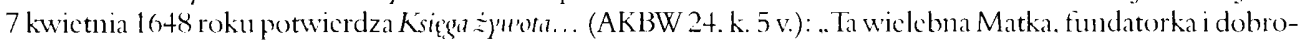
dzicjka nasza, najmilsza Matka Eufrazyja od świçtego Jacka, przcorysza tego naszego konwentu wileńskiego. z tego mizernegoświata przeniosła siç do wieczności Roku Pańskiego $16+8$ dnia 7 Aprila, godziny 7 rano, przeżywszy w zakonic ś[wiçtyın] lat 31, a wicku swego mając 57 . Zustawiła nas osicrocialyclı dzicci. W Wilnic bẹdąc na przelożeństwic”.

17 Księui, "k kónych się pisza dekryje..., rps AKBW 23, whladka.
} 
now Wielki Wtorek, 7 kwietnia 1648 roku. Zakonnice nie taiły swego żalu i placzu po śmierci przeoryszy. Kronikarka podkreśla cnoty Matki Eufrazji, zrozumienie i cierpliwość, pokorę wobec bliźniego. Również ludziom ubogim i słuzbie klasztornej okazywała wiele troski i miłości. Twierdziła, że ludzie ci nędzą swą i pracą zasłużyli na niebo. Kronikarka przytacza słowa przeoryszy:

...wielkie by moje szczęście było, kiedy bym ja pod nogami ich w niebie była ${ }^{18}$.

Matka Eufrazja udzielała jałmużny ubogim, śpiewającym albo żebrzącym na ulicy. W czasie mroźnej ziny podczas zwózki kamienni na budowę klasztoru, litując się nad pracownikami, nosiła im gorące piwo i chleb, dawała chusty. Dla podkreślenia ważności pracy rzemieślników sięgala do źródel ewangelicznych. Jej pochwała plebejskiego trudu, jego godności i wielkości ma charakter polemiczny wobec szlacheckiej pogardy dla zajęć plebejskich. System wartości oparty na apoteozie pracy starala się wpoić innym zakonnicom. Zachęcała siostry do okazywania sobie pomocy, wzajemnego usługiwania; wskazıjąc na ich wzajemną zależność, mówila:

...nie ma na świecie żadnego ubogiego większego nad was samych, bo ubogi pójdzie od domu do domu, wyżebrze sobie, wyśpiewa, wyprosi, że mu dadzą szeląg albo i grosz, za który kupi sobie, co chce, i zażyje jako chce i kiedy chce, ale siostra jako prawdziwie uboga nie kupi sobie niczego; - woli Bożej i miłości siostrzanej czeka, póki jej któna da jałmużnę, kiedy i jako; — nie jako ona chce, ale jako dadzą i kiedy, dlatego trzeba tego, abyście między sobą miały wielką milość jedna ku drugiej, osobliwie w okazyi, w potrzebie ${ }^{19}$.

Taki obraz pierwszej przeoryszy i fundatorki przynosi wileńska kronika klasztorna.

Na koniec przejdźmy do trzeciego znaczenia wyrazu „fundator” w pismach karmelitańskich. Fundatorem bywa nickiedy nazywana osoba, która wniosła do klasztoru znaczny posag, umożliwiając tym samym jego utrzymanie, a nawet rozbudowę czy nowe wyposażenie. W tym sensie fundatorką wileńskiego zgromadzenia byla Eufrazja od św. Kazimierza, I Ielena Sanguszkówna, córka Samuela Sanguszki, wojewody witebskiego, i Anny Zawiszanki. Wstępując w 1650 roku do klasztoru, ofiarowala 12 tysięcy złotych ${ }^{21}$. Na początku 1655 roku sporządziła testament, w którym cały należny jej po rodzicach majątek zapisała na dobro klasztoru.

W analizowanym przypadku na pewno nie można brać pod uwage jedynie pierwszego znaczenia słowa „fundator”. W tej sytuacji tylko teksty utworów zgromadzonych w rękopisie moga pomóc w ustaleniu, czy autorką ich była Teodora Piaseczyńska, czy też raczej Helena Sanguszkówna. Brakuje jednak wyraźnych przesłanek do datowania utworów. Można sądzić,

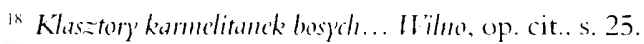

"Ibidem, s. 26.

20 Zob. Krotha kronika findacyi... rps AKBW 22, s. +15: cyt. za: B. J. Wanat. op. cit., s. 638. 
iż wiersze zanotowane w ręhopisie powstawały w ciągu wielu lat. Bohaterką licznych utworów jest młoda dziewczyna, nowicjuszka, której w obrzędzie adorowania figurki Dzieciątka przypadły różne role. Być może, teksty te pochodzą z okresu Bożego Narodzenia nie jednego roku, ale z kilku różnych lat. Mogło być jednak i tak, że wiersze te napisane zostały dla inuych mlodych zakonnic, nie mówią zatem o rzeczywistej roli autorki i nie odnoszą się jedynie do jej doświadczeń. O Matce Eufrazji od św. Jacka wiadomo, że, będąc w klasztorze św. Marcina, pisała wiersze; wzmiankę o tym fakcie znajdujemy w żywocie zakonnicy:

Na rekreacyjach siostry rozweselała, piosneczki o Pannie Najświętszej śpiewała, które sama składowała, nigdy po sobie najmnicjszego zaturbowania nie pokazala $^{2 !}$.

W Kantyczece 4: Imiç Jezus i Maryja pojawia się wątek autobiograficzny. Poetka pisze o sobie, iż utraciła matkę, i ból, jaki czuje po tej stracie, nigdy nie mija:

Pod te się garnę Imiona,

Bom jest bardzo utrapiona.

Z odejścia Matki kochany

Mnie w sieroctwie pozostaty

Widzisz, Jezu, me ciężkości,

Nieutulone żałości.

Póki życia mego staje,

Póty boleść nie ustaje (s. 68-69).

Niewielki ten - i jedyny - szczegól biograficzny nie pozwala jednak na wyciągnięcie konkretnych wniosków co do osoby autorki. O Matce Eufrazji od św. Kazimierza, Helenie Sanguszko, wiadomo, że straciła matkę w wieku dwóch lat. Ważniejsze w ustaleniu autorstwa tekstów wydają się szczególy zawarte w Kantyczce 9. Kantyczka ta nawiązuje do zagrożenia tatarskiego, tureckiego, moskiewskiego i szwedzkiego. Zapewne utwór wskazuje na połowę lat pięćdziesiątych XVII stulecia. Wiersz ten nie mógł powstać po 1683 roku, po bitwie wiedeńskiej, ani tym bardziej w latach dziewięćdziesiątych. Rok 1699, w którym zawarty został traktat w Karłowicach, oznaczal kres potęgi tureckiej i ustalał wiele zasadniczych elementów sytuacji międzynarodowej w Europie środkowo-wschodniej. Należy zatem przyjąć, iż wierszy tych nie mogły napisać ani wspommiana wcześniej siostra Eufrazja Bogumiła, ani również Matka Eufrazja od św. Jacka, która zmarła już w 1648 roku.

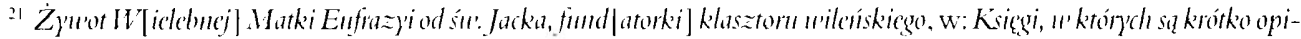

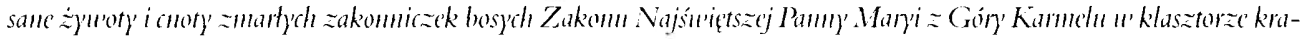
kouskim sur. Marcina od Roku Pariskiggo 1617. rps Bibliotcki Karmolitanck Bosych w Krakowic nr 253, s. 199. 
Podsumowując tok dotychczasowego wywodu, sądzimy, iz autorką pieśni byla Helena Sanguszkówna ${ }^{22}$. Dane historyczne dotyczące I Ieleny Sanguszkówny są niezwykle skąpe, część informacji biograficznych jedynie pośrednio dotyczy jej osoby, więcej szczegółów, jakie znajdıjemy w dostępnych źródłach, odnosi się do jej ojca, Samuela Sanguszki ${ }^{23}$.

Samuel Szymon Sanguszko, kniaź reprezentujący gałąź kowelską, której znaczenie ustalił, kasztelan, a następnie wojewoda witebski, był synem Andrzeja I Irehorowicza, dziedzica Smolna, Obolców, Horowla, i Zofii Sapieżanki, córki Pawla, kasztelana kijowskiego. Samuel był pierwszym ze swojej linii, który przeszedl z prawosławia na katolicyzm.

Z zachowanych mów i kazań pogrzebowych dowiadıjemy się, że w mlodości długie lata służył w wojsku, zwiedził wiele krajów, a także był dworzaninem pokojowym Zygmunta III. Brał udzial w wojnie ze Szwecją w 1601 roku; według Kaspra Niesieckiego uczestniczył również w wojnach moskiewskich 1605-1619. W maju 1620) r. został marszałkiem orszańskim, następnie postąpił na kasztelanię mścislawską i witebską, by w 1626 roku zostać wojewodą witebskim. W okresie kampanii smoleńskiej (1632-1634) bral udział w organizowaniu obrony Witebska. Nie bywał na sejmach. W konflikcie między Krzysztofem Radziwillem a Lwem Sapiehą (1630 r.) o majątek kopyski opowiedzial się po stronie Sapiehy. Jako wojewoda witebski odmówił w Orszy podpisania instrukcji poselskiej bez uprzedniego wymazania korzystnego dla Radziwilla wersetu w tej sprawie ${ }^{24}$.

Był posiadaczem dóbr w województwie mińskim i witebskim. W pobliżu Smolna (woj. witebskie) wybudowat okazałą rezydencję, nazywając ją Białyın Kowlem, dla uczczenia dawnej siedziby rodu, którą byl Kowel na Wołyniu. Jak podają heraldycy, interesował się naukami i w Białym Kowlı zgromadzil duży księgozbiór:

Pan jak mądrych ludzi, tak i księgi kochający, stąd bibliotekę swoją domową w różnych materiach godnymi autorami zagęśsil ${ }^{25}$.

W bibliotece tej znajdowaly się między innymi godzinki, wydane w Paryżu w roku 1505: Horae Dininae I irginis Mariae secundum vernum usum Romanonum, które Sanguszko otrzymał od Mikolaja Zenowicza. Wśród zgromadzonych w zamku sprzętów zwracal uwagę zegar,

...na którego wierzchołku śmierć widzieć było, na niej zaś kolumna światowej nikczemności symbola reprezentowała, która za każdym godziny wybijaniem obracala się ${ }^{2 n}$.

\footnotetext{
22 Autorstwo I Ieleny Sanguszkówny przyjmuje Stefan Nicznanowski, wskazując jedynic na wileńskie pocho-

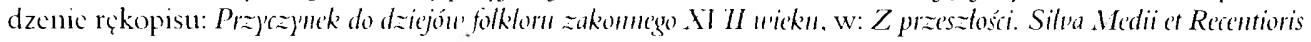
Aevi. Warszawa 1977. s. 156.

ZZob. Polski stoumik biograficall)' t. 3+, Wrochaw-Warszawa 1992-1993. s. 510-513 (aut. hasha: M. Nagiclski).

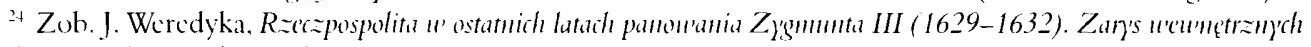
dzicjón polityczil'th. Opole 1978. s. 83.

${ }^{25}$ K. Niesiecki, Herbarz polski, wyd. J. N. Bobrowicza, t. 8, Lipsk 1841, s. 239.

2t Ibidem. s. 2+0).
} 
Samuel Sanguszko był nie tylko bibliofilem, lecz również pisarzem i artystą. Sporządzil genealogię rodu, a następnie przekazał synom z zaleceniem, by kontynuowali jej spisywanic.

Byl autorem mów okolicznościowych, miẹdzy innymi w roku 1599 wydal w Wilnie mowę z okazji małżeństwa Lwa Sapielıy z Elżbietą, córką Krzysztofa Radziwiłla. Zajmował się nadto malowaniem i rytowaniem.

Zmarł w listopadzie 1638 roku w Smolanach. Podczas pogrzebu w Wilnic 22 lutego 16.39 (zostal pochowany w Białym Kowlu) zwloki „wielkiego bohatyra, mądrego senatora” zostały przeprowadzone , z tych ozdobnych i pozonych murów Białokowelskich pod ciemne i żalosne lochy ziemne”, nie pieszo, lecz w ,foremnym pojeździe” ciągniętym nie przez trzy, jak to najczęściej bywalo, ale sześć par koni ${ }^{27}$.

Z małzeństwa z Anną Zawiszów miał Samuel jedenaścioro dzieci. Anna zmarła w 1619 roku w połogu, po narodzeniu ósmej córki. W 1627 roku Samuel poślubił w Wilnie I Ielenç Marcybelę Gosiewską. Synowie Anny i Samuela Sanguszków to: Kazimierz (zm. 165̄); H Hieronim, sufragan wileński, a następnie biskup smoleński; Jan Whadysław (16.52 r. ), protoplasta do dziś żyjących Sanguszków. Spośród ośmiu córek dwie zmarły w dzieciństwie, pozostałe to: Katarzyna, Zofia, Krystyna, I Ialszka (Elżbieta Anna) benedyktynka (ok. 1635 roku w Wilnie), Helena i Eufrozyna.

Informacje o I Iclenie Sanguszko znajdujemy w dokumentach klasztoru wileńskiego, na przykład w kronice klasztoru; heraldycy, wspominając córki Samuela, podają zaledwie imię zakonnicy $^{2 x}$.

Helena urodzila się około 1617 roku; doktadna data nie jest znana. Jak możua sądzić, wychowywała się w Białym Kowlu. Miała zaledwie dwa lata, kiedy zmarła jej matka, a dziesięćgdy ojciec ożenił się z Heleną Marcybelą Gosiewską. Jakie i gdzie otrzymała wyksztalcenie, nie wiadomo. Wzrastała w środowisku o wysokiej kulturze umysłowej i literackiej. Do klasztoru karmelitanek bosych w Wilnie wstąpila jako dojrzala kobieta, bo w trzydziestym trzecim roku życia. W księgach klasztorı wileńskiego pod datą ,rokı 1650 marca 11" odnotowano:

Za zwołaniem sióstr dzwonkiem zwyczajnym w kapitule wokalnej dawaliśmy glosy a kraty na górze przy bytności W[ielebnego] Ojca Michnała od Zwiastowania Naj[świętszej] Panny, wizytatora generalnego, na przyjęcie do habitu panny Heleny księżny Sanguszkówny, i przyjęta jest przez głosy tajemne dwunastu głosów 12, sióstr tyleż było 12, którymi kapituła złożona byla ${ }^{29}$.

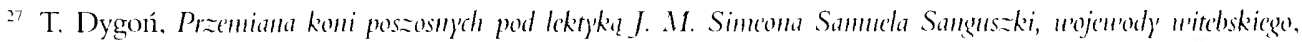

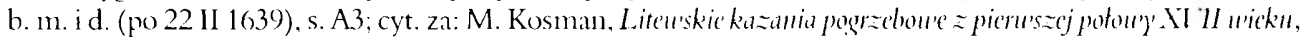
„Odrodzenic i Reformacja w Polsce”, t. 17, 1972. s. 107.

28 Zob. K. Niesiccki. Herbarz polski. op. cit., s. 240. Wśród dzieci Samucla nie wymienia Heleny: |A. A. Koniń-

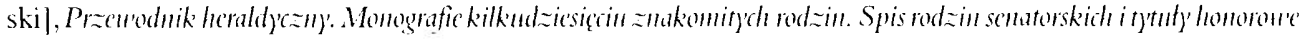

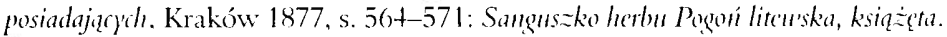

2" Ksiçi, w' krórych sic piszal dekeyje..., rps AKBW 23, k. 20) v. 
W tej samej księdze, nieco dalej, pod datą ,roku 1651 Februarii 5”, znajdujemy wiadomość o dopuszczeniu Heleny Sanguszkówny, siostry Eufrazji od św. Kazimierza do profesji:

Za zwołaniem sióstr dzwonkiem zwyczajnym w kapitule wokalnej dawaliśmy glosy na siostrę Eufiazyję od świętego Kazimierza, i przyjęta jest do profesyi przez glosy tajemme, głosów 11, a sióstr było 11, którymi kapituła złożona byla ${ }^{30}$.

I Ielena Sanguszkówna była czternastą profeską wileńskiego konwentu, co można stwierdzić na podstawie wykazu sióstr tego klasztoru ${ }^{31}$. Profesję zakonną złożyła 13 marca 1651 roku. Fakt ten odnotowano w Księdze źn'uta... ${ }^{32}$ :

Dnia 13 marca Roku Pańskiego 1651 okolo godziny 12 na pólzegarzu z południa siostra Eufrazyja od świętego Kazimierza (...) uczyniła profesyję w chórze przy obecności wszystkich sióstr tego klasztoru Józefa świętego w rękach Wielebnej Matki Konstancyjcj Beaty od Najś[więtszej] Panny Wniebowziętej, natenczas tego klasztoru przeoryszy, mając wicku swego lat 34.

I Ielena Sanguszkówna byla osobą odważną i umiejącą zachować spokój w najgroźniejszej nawet sytuacji. 28 lipca 1655 roku siostry opuściły Wilno, uchodząc przed nadciągającymi wojskami moskiewskimi. Udaly się do Grodna, a następnie do Lublina i dalej przez Beskidy na Węgry. Siostra Katarzyna od Chrystusa Pana, kronikarka klasztorna, odnotowała, iż w czasie przeprawy przez góry zagrożone było życie księżniczki Sanguszkówny. Gdy wóz obsunął się z górskiej drogi, trzymała się drzewa, aby nie spaść w przepaść ${ }^{33}$.

Musiała być osobą wybitną, mieć autorytet u sióstr i cieszyć się ich zaufaniem, skoro w wieku niespełna czterdziestu lat, zaledwie po pięciu latach pobytu w klasztorze, 21 marca 1656 roku obrana zostala przez zgromadzenie przeoryszą - w niezwykle trudnych dla sióstr okolicznościach, bo w czasie ucieczki przed Szwedami, na Morawach. Wiadomość o wyborze siostry Eufrazji od św. Kazimierza na przeoryszę zgromadzenia znajdujemy w księgach elekcji klasztoru wileńskiego. Pod datą: „Roku 1656 marca 21” zanotowano:

Odprawowała się elekcyja przełożonej, na której przez głosy tajemne obrana jest na przeoryszę siostra Eufrazyja od świętego Kazimierza za pierwszym razem jedenaście glosów, a sióstr było piętnaście 15, którymi kapituła złożona była. Przy tej elekcyi był W[ielebny] Ojciec Archaniol od ś[więtego] Michała definitor wtóry, natenczas przełożony nasz, i W[ielebny] Ociec Sebastian od

\footnotetext{
30) Ibidenls.

".14. M. Eufrazyja od świçtego Kazimicrza, 11clena Sanguszkówna, ksiçżniczka u[czynita] p[rofesyję] r[oku] 1651. umarla r[oku] 1679, mając wicku lat 63, w zakonic 29" (Kisegi, "ktory'th sié piszą clekeyje... rps AKBW 23, wkladka).

3 Kricga jylu'ota..., rps AKBW 2+. k. 32 v.

33 Zob. Klasztory karmelitanek bosych... Irilno. op. cit. s. 111.
} 
Wszystkich ŚŚ [Świętych], spowiednik nasz. Odprawowała się ta clekcyja w Lachowicach na Morawie, gdziechmy natenczas mieszkali $(\ldots)^{3+}$.

Funkcję swą Matka Eufrazja sprawowała do 16.59 roku, podczas pobytı zgromadzenia na Morawach.

W kronice klasztornej znajdujemy bardzo interesujący opis Bożego Narodzenia na Morawach. Ludność okoliczna Lachowic zgromadziła się na podwórzu przed kaplicą:

...śpiewali różne piosneczki po morawsku o Narodzeniu Pańskim. Był taki krzyk od różnych głosów, że aż po wszystkim kasztelu rozlegal się, a jako muzyka jaka, bardzo pięknie; nawet dziatki małe krzyczaly na wszystek głos, bez pochyby, że to się Panu bardzo podobało takie nabożeństwo w prostocie ich, a jeszcze tak daleką drogę podejmując, a z takia ochotą, i caly dzień nic nie jedząc, i na mrozie będąc, bo to śpiewanic trwalo nie mniej z pół godziny, a mróz tego dnia był bardzo wielki. (...) bo w tym kraju taki zwyczaj, że w kościołach msze św. śpiewa wszystkie pospólstwo, i nie po łacinie, ale po morawsku, tak że wszyscy znają i rozumieją, co we mszy śpiewają ${ }^{35}$.

Trzeci roku urzędu Matki Eufrazji od św. Kazimierza kończyl się jeszcze na Morawach. Prowincjal wyznaczył na urząd przeoryszy Konstancję od Najświętszej Panny Wnicbowziętej. W sierpniu 1659 roku, na polecenie prowincjała, siostry przyjechaly do Krakowa. Kronika klasztorna urywa się na opowiadaniu o pobycie zgromadzenia wileńskiego w krakowskim klasztorze św. Marcina. Owydarzeniach kolejnych lat krótko opowiada wydawca kroniki, ojciec Rafał Kalinowski. W 1660 roku zakonnice zostawały jeszcze w Krakowie. Tu wybrano nową przeoryszę: Teresę a Iesı Maria. W 1661 rokı siostry były już w Przemyślu, spędzily tu siedem lat, ale nie wiadomo, gdzie mieszkaly. Potem krótko przebywaly w Lublinie i wreszcie w 1667 roku powrócily do Wilna.

Wiadomość o śmierci I Jeleny Sanguszkówny znajdujemy w rękopiśmienmej Księd ze żyu’ota..., która podaje również nowy interesujący szczegól: drugie imię zakonne przeoryszy:

Matka Eufrazyja Magdalena od św[iętego] Kazimierza przeniosła się z tego świata do wieczności roku 1679 miesiąca Fébruarii [lutego] dnia 8, przeżywszy w zakonie ś[więtym] lat 29, a wieku swego mając lat 63, za przełożeństwa W[ielebnej] Matki Maryi Dominiki od Trójce Przenajśw[iętszej] w Wilnie” ${ }^{36}$.

Drugie imię Matki Eufrazji pojawia się raz jeszcze w tej księdze, i to we wlasnoręcznym podpisie przeoryszy: pod informacją o profesji siostry Marty od Zbawiciela, 8 maja 1658 roku w Lachowicach na Morawach ${ }^{37}$.

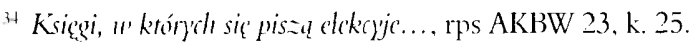

${ }^{35}$ Klas $\approx$ tory karmelitanck hosych... Irilno, op. cit. s. 89.

${ }^{36}$ Ksigga ̇ंurota..., rps AKBW 24, k. 33.

${ }^{37}$ Ibidem, k. 39. 
Czterdzieści jeden ,piosneczek” jest świadectwem zainteresowań literackich przeoryszy i niewątpliwego talentu poetyckiego. Utwory Sanguszkówny określone zostały jako: „piosneczki”, ,kantyczki”, co w środowisku karmelitanek oznaczalo pieśni bożonarodzeniowe, jednak przy bliższej obserwacji okazıje się, iż nie wszystkie wiersze uznać można za pieśni tematycznie związane z obchodami świąt Bożego Narodzenia. Trzydzieści utworów to pieśni bożonarodzeniowe, w dużej mierze związane z klasztornymi obyczajami, w przypadku pozostałych jedenastu związek z Bożym Narodzeniem jest luźny, niekiedy zaledwie zaznaczony jakimś wyrażeniem czy jedynie wyrazem: „Dziecię”; kilka spośród tych wierszy to utwory religijne, na przykład maryjne, których jednak w ogóle nie można uznać za kolędy. Przykładem takiego tekstu może być Kanty'czka 19: Śu'ięty Józef. Adresatem monologu jest postać tytulowa. Wypowiedź ma charakter prośby o ratunek w jakiejś bliżej nicokreślonej trudnej sytuacji życiowej zakonnicy. Jedynie w zakończeniu pojawia się sformułowanie wskazujące na okoliczności wypowiedzi. Bohaterka wypowiada się w obecności Tego, który ,jest w żłobie położony”.

„Piosneczki” reprezentują religijna poezję dojrzałego baroku. Wiersze te dowodzą, iz w świecie kultury symbolicznej Matka Eufrazja poruszała się ze znajomością rzeczy, z dużą swobodą, a nawet z pewnym wdziękiem. Zajmowanie się twórczością poetycką musiało być w środowisku karmelitanek zajęciem godnym i cenionym, skoro poezjowaniem trudniła się przeorysza klasztoru i fakt ten skwapliwie odnotowano, nie pozostawiając jej utworów, jak dziesiątki innych wierszy, anonimowymi. Zapewne żywa była wśród karmelitanek pamięć o tym, że poezję uprawiali wielcy hiszpańscy założyciele zgromadzenia, św. Teresa z Avili i św. Jan od Krzyża. Być może, wiersze opatrzone informacją, iż są autorstwa osoby tak wysoko urodzonej jak Helena Sanguszkówna, cenionej w środowisku, skoro uhonorowano ją godnością przeoryszy, zyskiwaly na popularności wśród zakonnic i byly troskliwie przechowywane.

$\mathrm{Na}$ koniec warto dodać, iż wydany w 1999 roku Stounik polskich karmelitanek bosych 1612-1914 autorstwa Czeslawa Gila, historyka Zakonu, uświadamia istnienie w XVII wieku jeszcze jednej „Matki Eufrazyi”. Byla nią Eufrazja Teresa od Zwiastowania NMP — Anna Pajewska, córka Piotra i Katarzyny Pieczychojskiej, urodzona 24 grudnia 1643 roku w województwie lubelskim. Wstąpiła do klasztoru Niepokalanego Poczęcia NMP w Lublinie w wieku 14 lat, po ukończeniu 16 roku życia złożyła śluby zakonne. 11 października 1665 roku wyjechała na fundację do Poznania, gdzie kilkakrotnie byla przeoryszą (od 1683? do 1704). Była więc fundaturką klasztoru poznańskiego, siódınego klasztoru karmelitanek bosych na ziemiach polskich. Przez całe życie ciężko chorowała, mimo to pracowała fizycznie, zwlaszcza na początku fundacji poznańskiej, kiedy zgromadzenie nie miało żadnej konwerski. W 1699 roku na skutek upadku ze schodów wybiła sobie oko i doznała innych obrażeń. Gdy w czasie oblężenia Poznania w 1704 roku stan jej ulegl szczególnemu pogorszeniu, zgromadzenie zwrócilo się do paulinów na Jasnej Górze z prośbą o modlitwę w intencji chorej przed obrazem Matki Bożej. Za jej przełożeństwa (w 1678 roku) zgromadzenie wprowadzilo się do nowego klasztoru, miało miejsce poświęcenie kościoła i dzwonów. Przez cale życie ofiarnie słu- 
żyła chorym. Zmarła 8 października 1705 roku. Jest autorką opisu fundacji poznańskiej ${ }^{38}$. Może jest również autorką kantyczek z reçopisu kórnickiego, chociaż nic nie wskazuje na to, ze rękopis powstał w klasztorze poznańskim. Mogłoby to jednak thumaczyć obecność rękopisu w wielkopolskim zbiorze „niejakiego Kokoszyńskiego”. W świetle tych ostatnich informacji sprawa autorstwa i proweniencji rękopisu kómickiego wydaje się otwarta, chociaż należy podkreślić, iż najwięcej faktów wskazuje na klasztor wileński i autorstwo I Ieleny Sanguszkówny. 